\title{
Inve'stigation Sound Frequency of Tire Failure in Drum Test Machine
}

\author{
Heru Priyono \\ Department of Mechanical Engineering \\ Swiss German University \\ Tangerang 15143, Indonesia \\ Email: herupriyono@ymail.com
}

\author{
Widi Setiawan \\ Department of Mechanical Engineering \\ Swiss German University \\ Tangerang 15143, Indonesia
}

\begin{abstract}
Indoor test on the tire using the drum test machine by applying pressure and rotation according to the test method that has been determined until the tire is damaged, even until the tire explodes. This is done by measuring the maximum strength of the tire. Damage or explosion on the tire when testing takes place is not expected to occur, because this explosion can damage the drum test machine. For research and development purposes it is necessary to find out the location of the initial damage to the tire so that it can be improved on the weak part of the tire. A few moments before the tire is damaged a lump on the tire occurs and produces an unusual sound. This change in the frequency of sound that occurs before and when the initial tire is damaged will be analyzed, which will then be used to create a tire damage detection system so that the test can be stopped when the tire has initial damage.
\end{abstract}

Keywords: Indoor Test, Drum Test, Sound Frequency, FFT, Frequency Analysis.

\section{INTRODUCTION}

Testing the performance of motor vehicle tires is done in various ways. One of them is indoor test testing using a machine called "Drum Test Machine" (Fig.1). Testing is done by pressing the tire with a certain pressure on a drum that rotates at a certain speed until the tire is damaged. Testing until the tire explodes as much as possible avoided because the explosion can cause damage to the engine components. In tire testing aimed at research and development, it is also necessary a condition where the test should be stopped when the tire is indicated to be exploding, so it can be known which part of the tire construction causes the tire to explode.

There are two methods applied to the drum test machine to meet this need. First is install the wire sensor on the outside of the tire's tread with a distance of $\pm 3 \mathrm{~cm}$ from the tire's tread and its connected to the sensor (limit switch). The second is install the $\mathrm{Y}$ probe from the end of the rim (rim) to the left side of the rim (rim) to the right with a distance of $\pm 3 \mathrm{~cm}$, the form of iron wire made adjusted to the contour of the tire, then connected to the sensor (limit switch).

The working system of the above two methods is when the tire is damaged, the tire will change shape, expands on certain parts due to air pressure in the tire and touch the wire sensor or Y Probe to make limit switch work to stop testing.

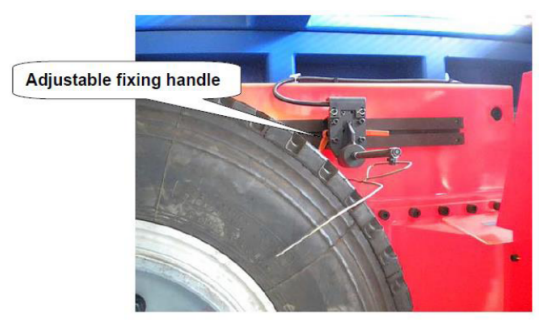

Fig. 1. Current Existing System.

\section{OBJECTIVES}

The objectives of the study comprising of:

- To analyze the sound sources arises during the tire testing process on the drum test machine.

- To analyze the sound frequencies changes that occur when the tire is damaged.

- To analyze the sound frequency spectrum caused by tire explosion.

\section{Theoritical Perspective}

Exploding tires should be avoided because the explosions that occur will damage the engine components. Causes the stop machine to be repaired so that the engine efficiency will go down. In addition to research and development needs a system that can stop the tire just before the tire exploded. This is needed to analyze the location and cause of the burst tire. If the tire already explodes it will be difficult to determine the weakest location of the tire construction causing the tire to break down or explode. The safety device on the machine can only stop testing when the tire has exploded, stopping the load pressing the tire so that when the tire exploded the rim attached to the tire is not in contact with the drum that is still spinning fast enough. When a tire is damaged the sound caused by friction between the tire and the drum has a distinctive sound intensity. This is quite recognizable by the operators who operate the machine, so that when the voice appears 
the operator will immediately stop the drum test machine manually because the tires can be inferred damaged.

The sound caused by the damaged and almost explosive tire is the author of the analysis with the aim of stopping the machine automatically.

\section{A. Typical Failure Tire Testing}

By the above testing, conditions tire typically will get a failure with kind of example failure as shown in Figure 2.

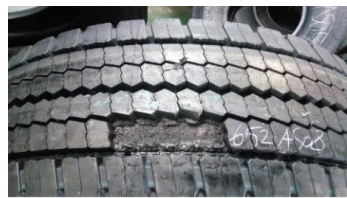

(a)

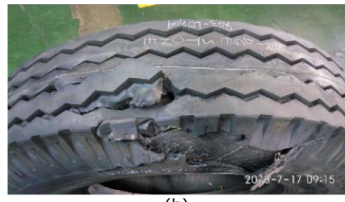

(b)

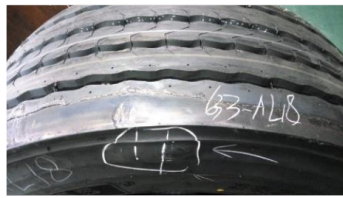

(c)

Fig. 2. Typical Failures tires after testing on the drum for (a) High-Speed, remarks: tread chunking, that is part of tire tread separation, (b) High-Speed, remarks: cord broken up, that is part of the body ply which is broken up at the sidewall area, and (c) Endurance, remarks: sidewall separation, that is sidewall rubber of tire separation from body ply.

\section{B. Endurance Test Method}

An endurance test is an indoor test method that uses a drum test machine where the tire is rotated at a fixed speed and the tire is given a gradually increasing load according to the specified requirements, as demonstrated by Table I.

\section{High-Speed Test Method}

The high-speed test is an indoor test method using a drum test machine where the tire is swiveled at an increasing speed and press with a fixed load, as demonstrated by Table II.

\section{DESIGN OF EXPERIMENTAL}

Material equipment and setting position of the design of the experiment can be seen in Figure 3.
TABLE I

Endurance Test Method

\begin{tabular}{ccccl}
\hline Step & Time $(\mathrm{hr})$ & Speed $(\mathrm{Km} / \mathrm{hr})$ & Load $(\mathrm{Kg})$ & Remark \\
\hline 1 & 7 & 35 & 2000 & $\begin{array}{l}\text { Speed Fix - Load } \\
\text { Increase }\end{array}$ \\
2 & 16 & 35 & 3000 & \\
3 & 24 & 35 & 4000 & \\
4 & 6 & 35 & 5000 & \\
5 & 6 & 35 & 6000 & \\
\hline
\end{tabular}

TABLE II

High-SpeEd Test Method

\begin{tabular}{ccccl}
\hline Step & Time $(\mathrm{hr})$ & Speed $(\mathrm{Km} / \mathrm{hr})$ & Load $(\mathrm{Kg})$ & Remark \\
\hline 1 & 7 & 30 & 3000 & $\begin{array}{l}\text { Speed Fix - Load } \\
\text { Increase }\end{array}$ \\
2 & 16 & 50 & 3000 & \\
3 & 24 & 70 & 3000 & \\
4 & 6 & 90 & 3000 & \\
5 & 6 & 110 & 3000 & \\
\hline
\end{tabular}

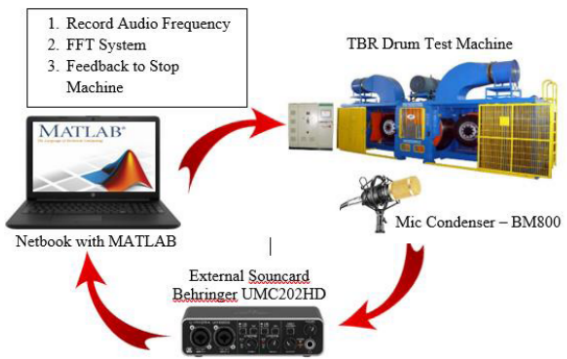

Fig. 3. Schematic Measurement of Sound Frequency.

\section{A. Install Mic Condenser BM800}

Figure 4 shows how the mic condenser BM800 installed inside the TBR drum test chine. The function is to record sound appear from the tire during tire test. The distance between the microphone and the sound source, which is the friction between the tires and the drum machine, is $70 \mathrm{~cm}$.

\section{B. Install Behringer Uphoria UMC202HD in TBR Drum test machine}

Figure 5 shows how the external soundcard Behringer UM202HD taken place inside the panel control TBR drum test machine. The function is to convert the analog signal to digital signal from condenser mic during tire test. Behringer uphoria UMC202HD is connected with a laptop using a USB cable, as a medium to transfer data as well as a power cable. The 


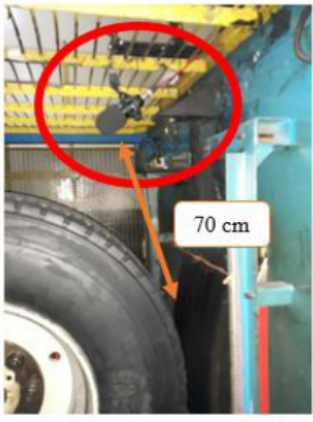

Fig. 4. BM800 in TBR Drum Test Machine.

condenser mic cable is connected to the Uphoria UMC202HD on line input 1.

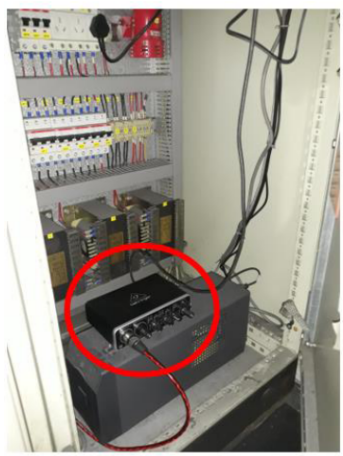

Fig. 5. Behringer Uphoria UMC202HD in TBR Drum test machine.

The Behringer U-Phoria UMC202HD USB Audio Interface is a studio in a box engineered for professional level recordings with microphone, guitar, bass and keyboard connectivity. The $2 \times 2$ interface features audiophile quality 24 -bit/ $192 \mathrm{kHz}$ resolution for a truly professional sound whilst $2 \times$ studiograde Midas mic preamps ensure premium vocal recordings and even includes $+48 \mathrm{~V}$ phantom power. The UMC202HD is compatible with a wide array of popular recording software and also offers zero-latency monitoring. Each of these features is safely protected with the impact-resistant metal chassis.

Sampling frequency from an audio device Uphoria UMC202HD is $192 \mathrm{kHz}$, so that the highest frequency is 96 $\mathrm{kHz}$. At the condenser mic the upper cut-off frequency used is $15,192 \mathrm{kHz}$. 1 decade from upper cut-off frequency mic condenser is $10 \times 15,192 \mathrm{kHz}=150,192 \mathrm{kHz}$. Highest frequency audio device $<1$ decade from upper cut-off frequency If we calculate the highest frequency $=1$ decade from the upper cut-off, then the maximum amplitude noise to signal ratio is due to the effect of aliasing $=-20 \mathrm{~dB}$ So the conclusion is by using UMC202HD audio devices with sampling frequency of $192 \mathrm{kHz}$, signal to noise ratio $<20 \mathrm{~dB}$.

\section{Record Microphone Input}

Figure 6 shows how the laptop taken place out-side the panel control TBR drum test machine. The laptop function is to record and analysis the sound during tire test. Recording is done with the 30-minute every step of the testing method and stored with a file with the extension wav.

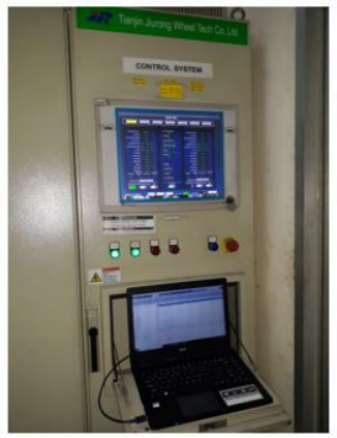

Fig. 6. Record Data.

\section{EXPERIMENT RESULT}

\section{A. Record Data Speed}

The recording is done using a laptop with Matlab software. Done by running the engine without load, only the drum rotates with 4 stages of speed, $40 \mathrm{Km} / \mathrm{h}, 50 \mathrm{Km} / \mathrm{h}, 60 \mathrm{Km} / \mathrm{h}$ and $70 \mathrm{Km} / \mathrm{h}$. Each stage of speed is run with a duration of 2 minutes and a total time of 8 minutes, show as Figure 7 and recording is done after a stable speed drum with a duration of 30 seconds. In this condition, the sound source is the Drum Motor, Drum Machine, and Vanbelt which connects the motor to the drum machine.

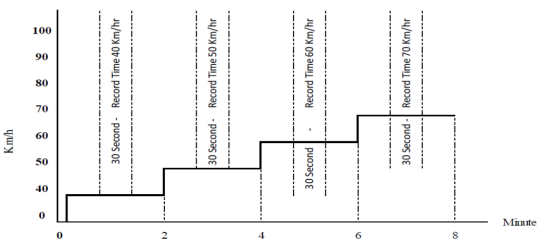

Fig. 7. Record Data Speed. 
From the illustration Figure 8, the first column is the result of recording the drum machine in Time Domain. While the second column describes the recordings that have been changed into Domain Frequency with FFT. At the frequency of domains, one peak appears which is concluded as the frequency of the Drum Machine rotation.
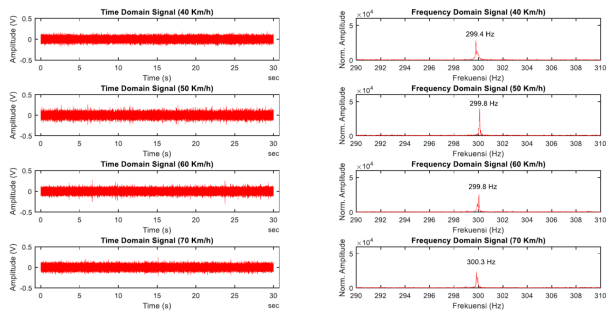

Fig. 8. Record Data Speed Drum - No Load.

\section{B. Record Data Speed and Load Normal Condition}

The recording is done on a normal drum test machine with a speed of $50 \mathrm{Km} / \mathrm{h}$ and $60 \mathrm{Km} / \mathrm{h}$ and the load varies. I chose this speed because the indoor testing of TBR tire tests is in the speed range $50-60 \mathrm{Km} / \mathrm{h}$, show as in Figure 9.
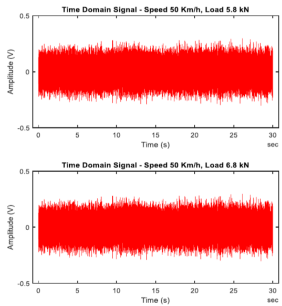

Fig. 9. Normal Condition $50 \mathrm{Km} / \mathrm{h}$.

\section{Record Data Speed and Load Abnormal Condition}

The recording is done on a normal drum test machine with a speed of $50 \mathrm{Km} / \mathrm{h}$ and $60 \mathrm{Km} / \mathrm{h}$ and the load $6.8 \mathrm{kN}$ with the indicated tire damaged. The load and speed were chosen as experimental material because TBR tires are often damaged in tests with speeds of $50 \mathrm{Km} / \mathrm{h}$ and $60 \mathrm{Km} / \mathrm{h}$ if they have reached a load above $6.8 \mathrm{kN}$ (Fig.10).

\section{CONCLUSION}

From observation on the result of the experiment, we can conclude that (i) the frequency spectrum remains the same when a tire runs on the drum at good condition and no failure indication, (ii) the frequency spectrum change indicates a change of tire structure, and (iii) based on Fig.10, we conclude that tire frequency spectrum and its change can be identified using Fast Fourier Transform.
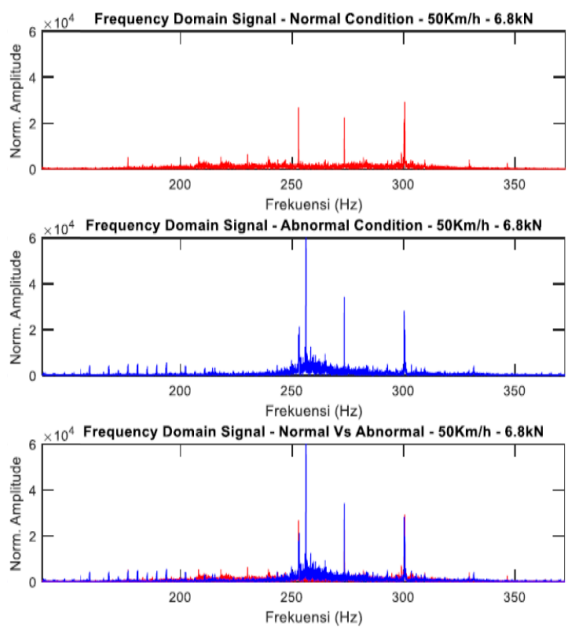

Fig. 10. Normal against Abnormal Condition in $50 \mathrm{Km} / \mathrm{h} 6.8 \mathrm{kN}$.

\section{RECOMMENDATIONS}

Based on the results, we provide recommendation as follows:

- Use this frequency change as detection for tire failure to activate the actuator. The actuator will work to give a signal to the engine to stop testing. Further research can be done for applications to become real applications.

- Continue collect sound frequency measurements data for tire failure modes as continuous improvement for the implementation.

\section{REFERENCES}

[1] Irmawati, Dessy, Modifikasi Alat Medis Stetoskop untuk Monitoring Suara Jantung Menggunakan Tampilan GUI Matlab., 2018

[2] Susanto, Budi, Identifikasi Suara Pria dan Wanita Berdasarkan Frekuensi Suara, 2011

[3] JK Tyre \& Industries Ltd. (n.d.). Know Your Tyre - Tyre Types. Retrieved from https://www.jktyre.com/knowyourtyre.aspx [Accesse : 22 Des 2018]

[4] Diktat Pusdiklat BATAN. Teknik Pengolahan Isyarat \& Kendali Digital. 2005

[5] Tianjin Jiurong Wheel Tech Co., Ltd., Manual Machine Drum Test TBR (B1602). In Manual Machine Drum Test TBR (B1602). Tianjin Jiurong Wheel Tech Co., Ltd. 2013

[6] Tanjin Jiurong Wheel Tech Co., Ltd., TB Wheel Radial Fatique Test Machine. Retrieved from http://jiurongwheel.com/Product_Show.asp?ID= 136 [Accessed 2212 2018]

[7] Abdulmail. Sinyal Analog dan Sinyal Digital. 22 September 2010.

[8] Lukman, Arif., Gojali, Elli A., Simulasi Algoritma Dasar Pengacakan Data Audio Menggunakan Matlab. Jurnal Teknologi Informasi, Vol.5,No. 1, pp. 5-7. 2004

[9] Li Tan, Jean Jiang, Digital Signal Processing - Fundamentals and Applications. Elsevier Inc. 2013

[10] A.N. Gent and J.D. Walter, The new pneumatic tires, NHTSA US DOT 2005

[11] The Europe Tyre and Rim Technical Organisation, ETRTO Standar manual, 2016 